\title{
A COVID-19-járvány miatt bevezetett járványügyi intézkedések hatása a hasi sebészeti ellátásra a Bajcsy-Zsilinszky Kórházban
}

\author{
Benedek Zsófia dr. ${ }^{1,2}$ - Molnár-Gallatz Zsolt dr. ${ }^{3}$ \\ ${ }^{1}$ Bajcsy-Zsilinszky Kórház és Rendelőintézet, Budapest \\ ${ }^{2}$ Semmelweis Egyetem Mentális Egészségtudományok Doktori Iskola, Budapest \\ ${ }^{3}$ Észak-Közép-budai Centrum, Új Szent János Kórház és Szakrendelő, Budapest
}

\begin{abstract}
Bevezetés: 2020 első negyedévében a koronavírus gyors terjedése, az általa okozott betegségek súlyos következményei miatt világszerte, így hazánkban is megváltozott az egészségügyi ellátás. Közleményünkben bemutatjuk, hogyan befolyásolták egy fővárosi kórház hasi sebészeti osztályának betegellátását, az ellátott esetek számát és összetételét a járvány első, 2020-as tavaszi hulláma idején bevezetett járványügyi korlátozó intézkedések.

Célkitüzés: Célunk az volt, hogy adatokkal összehasonlítsuk 2021., 2020. és 2019. április sebészeti fekvőbeteg-ellátásának jellemzőit osztályunkon.

Módszer: A 2019. április 1. és 30., 2020. április 1. és 30. és 2021. április 1. és 30. közötti időszakokban a fővárosi Bajcsy-Zsilinszky Kórház Sebészeti, Érsebészeti és Mellkassebészeti Osztályán az általános sebészeti fekvőbeteg-ellátás keretében végzett hasi sebészeti mútéti beavatkozások adatait hasonlítottuk össze. Az adatokat MS Excel és SPSS (25. verzió) programokkal vizsgáltuk, és statisztikai elemzéseket végeztünk.

Eredmények: A bevonási kritériumoknak 197 eset felelt meg 2019 áprilisában, 77 eset 2020 áprilisában és 95 eset 2021 áprilisában. Az osztályos ápolási idő 2019-ben átlagosan 4,51 nap, míg 2020-ban 6,31 nap és 2021-ben 6,29 nap volt. 2019-ben napi átlagban 2,54 akut és 6,2 tervezett mútét, 2020-ban napi 2 akut és 1 tervezett mütét, míg 2021-ben napi 2,8 akut és 0,9 tervezett mütét történt. Az 1 före jutó kísérő betegségek száma a tervezett mútétek esetében 2019-ben 1,69 volt, míg 2020-ban 2,97, 2021-ben pedig 2,74. Az akut mútétre került betegek kísérő betegségeinek eloszlása szignifikánsan eltért, l betegre 2019-ben átlagosan 2,5, 2020-ban 3,75, míg 2021-ben 3,25 kísérő betegség jutott. Az akut sebészeti ellátáson átesett betegek halálozása 2019-ben 11,8\%, 2020-ban 13,33\%, 2021 -ben $15,66 \%$ volt.

Következtetés: A COVID-19-járvány miatt bevezetett járványügyi intézkedések velejárója volt, hogy hasi sebészeti osztályunkon lényegesen kevesebb elektív mútétet végeztünk. A sürgősséggel ellátott páciensek kísérő betegségeinek száma szignifikánsan emelkedett, valószínúleg ezzel magyarázható a halálesetek számának párhuzamos emelkedése. Orv Hetil. 2021; 162(44): 1761-1768.
\end{abstract}

Kulcsszavak: COVID-19-járvány, hasi sebészet, tervezett és sürgős sebészi beavatkozások

\section{Impact of the epidemiological instructions due to the COVID-19 pandemic on general surgical care at the Bajcsy-Zsilinszky Hospital in Budapest}

Introduction: Due to the rapid spread of the coronavirus and the serious consequences of the diseases, the organization of healthcare worldwide changed in the first quarter of 2020. We show effects of restriction due to protection against the first (April 2020) wave of coronavirus in our surgery care.

Objective: The aim of this study was to compare characteristics of general surgical inpatient care in April 2020 and April 2021 with April 2019 by the hospital database.

Method: We compared general surgical data of April 2021,2020, and 2019 from the medical informatic system at the General, Vascular and Thoracal Surgery Department of the Bajcsy-Zsilinszky Hospital in Budapest. The data were analyzed with MS Excel and SPSS (version 25) programs.

Results: Study inclusion criteria met with 197 cases from April 2019, 77 cases from April 2020, and 95 cases from April 2021. Length of stay at surgical department was average 4.51 days in 2019, 6.31 days in 2020, and 6.29 days in 2021. In 2019, average 2.54 urgent and 6.2 planned operations were done, in 2020 these numbers were average 
2 and 1 per day and in 2021, 2.8 urgent and 0.9 planned surgical procedures were performed. The number of comorbidities per capita in elective cases was 1.69 in 2019, 2.97 in 2020, and 2.74 in 2021. Distribution of coded co-morbidities in the case of patients with urgent surgery was significantly different between the groups, in 2019 it was 2.5 , in 20203.75 , and in 20213.25 per capita. Postoperative mortality at the same care of patients after urgent surgery was $11.8 \%$ in $2019,13.33 \%$ in 2020 , and $15.66 \%$ in 2021 .

Conclusion: Due to the government instructions because of COVID-19 pandemic, less elective general surgery procedures were performed in our department. Co-morbidities of patients with urgent surgery significantly increased, probably this is responsible for the increase of postoperative mortality.

Keywords: COVID-19 pandemic, general surgery, elective and urgent surgical procedures

Benedek Zs, Molnár-Gallatz Zs. [Impact of the epidemiological instructions due to the COVID-19 pandemic on general surgical care at the Bajcsy-Zsilinszky Hospital in Budapest]. Orv Hetil. 2021; 162(44): 1761-1768.

(Beérkezett: 2021. május 9.; elfogadva: 2021. augusztus 31.)

\begin{abstract}
Rövidítések
$\mathrm{ANOVA}=($ analysis of variance $)$ varianciaanalízis; $\mathrm{BNO}=\mathrm{Be}-$ tegségek Nemzetközi Osztályozása; COVID-19 = (coronavirus disease 2019) koronavírus-betegség 2019; EMMI = Emberi Erőforrások Minisztériuma; ESAS = Elective Surgery Acuity Scale; IKEB = Intézményi Kutatásetikai Bizottság; OENO = Orvosi Eljárások Nemzetközi Osztályozása; PCR = (polymerase chain reaction) polimeráz-láncreakció; $\mathrm{SD}=$ standard deviáció
\end{abstract}

Az új típusú koronavírus okozta betegség, a COVID-19 $[1,2]$ gyors terjedése és súlyos következményei miatt a 2020. év első harmadában világszerte megváltozott a betegellátás szervezése [3]. A nem COVID-19 egészségügyi ellátás szükségszerú átszervezése miatt a szakmai szervezetek ajánlásokat, irányelveket fogalmaztak meg [4-6], amelyek segítették a betegellátást a csökkent mútói és ágykapacitások mellett (például: Elective Surgery Acuity Scale [ESAS] döntéssegító lista). A COVID19-pandémia első hullámában a Magyar Sebész Társaság honlapján is megjelentek a sebészeti betegek ellátására vonatkozó ajánlások [7]; ezen ajánlások használata segítséget nyújtott a mütétek elvégzésének és elhalasztásának eldöntésében a veszélyhelyzetben, amelyet hazánkban 2020. március 11-én hirdettek ki [8]. Az Emberi Erőforrások Minisztériuma elrendelte, hogy 2020. március 16-tól a veszélyhelyzet megszúnéséig el kell halasztani minden, azonnali egészségügyi ellátást nem igénylő beavatkozást, és a 2020. április 7-én kiadott EMMI-utasítás szerint a Nemzeti Egészségbiztosítási Alapkezelő által finanszírozott teljes ágykapacitás minimum 60\%-át COVID-19-fertőzött betegek ellátására kellett alkalmassá tenni. Az intézkedések a vizsgálatban részt vevő sebészeti osztályt is érintették. A tervezett és nem rosszindulatú daganatos betegségek miatti mútétek elhalasztásra kerültek, a várólistákra új mútéti előjegyzést nem lehetett rögzíteni, és a sebészeti osztály ágyszámának 60\%-át felszabadították. Közleményünkben bemutatjuk, hogy a COVID-19-pandémia miatti korlátozások és a járvány 2020-as első, illetve a 2021-es tavaszi hulláma milyen hatással voltak egy fővárosi kórház sebészeti osztályának betegellátására. A változások szemléltetéséhez a 2019-es év április hónapjának betegforgalmi és -ellátási adataihoz hasonlítottuk a 2020. áprilisi (az első hullám tetőzését magában foglaló időszak [9]) és a 2021. áprilisi (harmadik hullám) azonos típusú adatokat. Az ellátásszervezés szempontjából kiemelendő, hogy a vizsgálati időszakok alatt a sebészeti osztály minden nap akut felvételes ügyeletet látott el, a területi ellátási kötelezettségnek megfelelő pesti kerületek és a Budapest környéki települések vonatkozásában. Nagy különbséget jelentett a 2020-as és 2021-es elláási időszak és a 2019-es között, hogy 2019ben a sürgősségi ellátás mellett a hasi sebészeti kórképek tervezett mútétjeit is végezték a vizsgált osztályon.

Célunk az volt, hogy összehasonlítsuk 2020. és 2021. április, valamint 2019. április hónap sebészeti fekvőbeteg-ellátásának jellemző́it.

\section{Módszer}

A fővárosi Bajcsy-Zsilinszky Kórház sebészeti osztályának hasi sebészeti részlegén ellátott betegek adatai az Intézményi Kutatásetikai Bizottság (IKEB) engedélyével kerültek összegyújtésre a kórházi medikai rendszerből a jelen kutatás számára. Az esetkiválasztási szempontok a következők voltak: olyan, 18 évesnél idősebb betegek adatait vizsgáltuk, akiknél a 2019. április 1 . és 30. közötti, a 2020. április 1 . és 30. közötti és a 2021. április 1 . és 30. közötti időszakban hasi sebészeti mútéti beavatkozás történt fekvőbeteg-ellátást igénylő megjelenés keretében. A kutatásba a sebészeti osztályos megjelenésen kívül azon betegek adatai is bevonásra kerültek, akiknél kórházunk más osztályos (például intenzív vagy COVID-osztály) megjelenése során történt hasi sebészeti beavatkozás az adott időszak alatt. A kutatásba nem kerültek bele azon betegek adatai, akik sebészi megfigyelésre kerültek felvételre, és nem történt mútét az ellátásuk során, illetve akiknél járóbeteg-szakellátás keretében történt a sebészi beavatkozás. A betegek ellátási eseményeihez a rögzített adatok alapján az életkort, a beavatkozások (OENO-) 


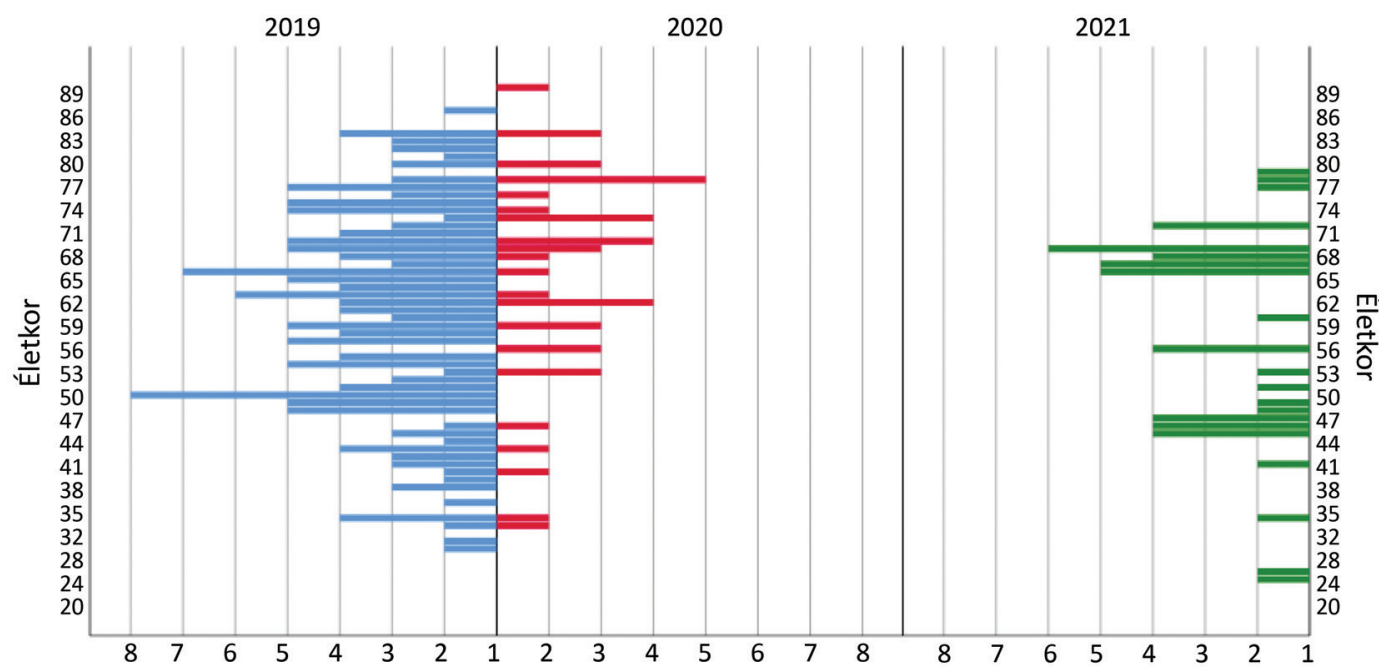

1. ábra | A vizsgált 2019., 2020., 2021. év áprilisában hasi sebészeti mútétre került betegek életkor szerinti megoszlása hisztogramon

kódjait, az ápolást indokló fódiagnózist (3-as BNO), a kísérő betegségeket (5-ös BNO, kiegészítve a sebészeti kórlapok anamnézise és a medikai rendszerben fellelhető betegadatok alapján) és a szövődménykódokat (4-es BNO), a hasi sebészeti ellátást követő betegút vizsgálata kapcsán az intézetünkből történő elbocsátáskor feltüntetett további sors kódját gyújtöttük össze a medikai rendszerből. 2020-ban és 2021-ben a kórház mikrobiológiai részlegének segítségével a betegek rendelkezésre álló COVID-PCR-tesztjeinek eredményei is összegzésre kerültek.

Számításainkat a Microsoft Excel (Microsoft Corporation, Redmond, WA, USA) és az SPSS 25-ös verziószámú program (IBM Corporation, Armonk, NY, USA) segítségével végeztük el. A vizsgálat során leíró statisztikai elemzéseket, kereszttáblás elemzéseket, egyszempontos varianciaelemzéseket végeztünk. Eredményeinket 95\%-os konfidenciaintervallumon értékeltük.

1. táblázat A vizsgálatban részt vevő betegek nem, átlagéletkor, létszám, megjelenési időszak szerinti eloszlása

\begin{tabular}{lllll}
\hline $\begin{array}{l}\text { A megjelenés } \\
\text { időszaka }\end{array}$ & Nem & $\begin{array}{l}\text { Átlagéletkor } \\
(\text { év) }\end{array}$ & $\begin{array}{l}\text { Létszám } \\
\text { (fó })\end{array}$ & Szórás \\
\hline 2019. április & Nő & 56,18 & 96 & 15,863 \\
& Férfi & 59,45 & 101 & 15,446 \\
& Összes & 57,85 & 197 & 15,696 \\
\hline 2020. április & Nó & 60,63 & 49 & 15,895 \\
& Férfi & 62,25 & 28 & 19,415 \\
& Összes & 61,22 & 77 & 17,149 \\
\hline 2021. április & Nó & 59,42 & 48 & 17,482 \\
& Férfi & 56,55 & 47 & 15,808 \\
& Összes & 58,00 & 95 & 16,648 \\
\hline
\end{tabular}

\section{Eredmények}

A bevonási kritériumoknak a kijelölt három naptári hónap alatt összesen 369 általános sebészeti mütéten átesett beteg adata felelt meg; 197 megjelenés 2019 áprilisában , 77 megjelenés 2020 áprilisában, 95 pedig 2021 áprilisában. 2019 áprilisában a mütétre került betegek körében az általános sebészeti osztály betegforgalma 2,5-szeres volt a 2020-as év és 2,16-szeres a 2021-es év azonos időszakához képest. Az általános sebészeti osztályon az ápolási időszakok hossza a három csoportban szignifikánsan eltért egymástól: 2019 áprilisában átlagosan 4,51 nap (SD: 5,67), 2020 áprilisában 6,31 nap (SD: 4,81), 2021 áprilisában pedig 6,29 nap (SD: 6,77) volt $(\mathrm{p}<0,05)$.

A kutatásban szereplő betegek átlagéletkora 2019-ben és 2021-ben közel 3 évvel alacsonyabb volt 2020-hoz képest, a különbséget az 1. táblázatban szemléltetjük. A három időintervallumban kezelt betegek koreloszlásának vizsgálatakor feltúnő különbséget tapasztaltunk (1. ábra): míg 2019-ben az 50 év körüli betegek aránya kiugróan magas a hisztogramon, addig 2020-ban a 4550 éves korcsoport szinte teljesen hiányzik, 2021-ben

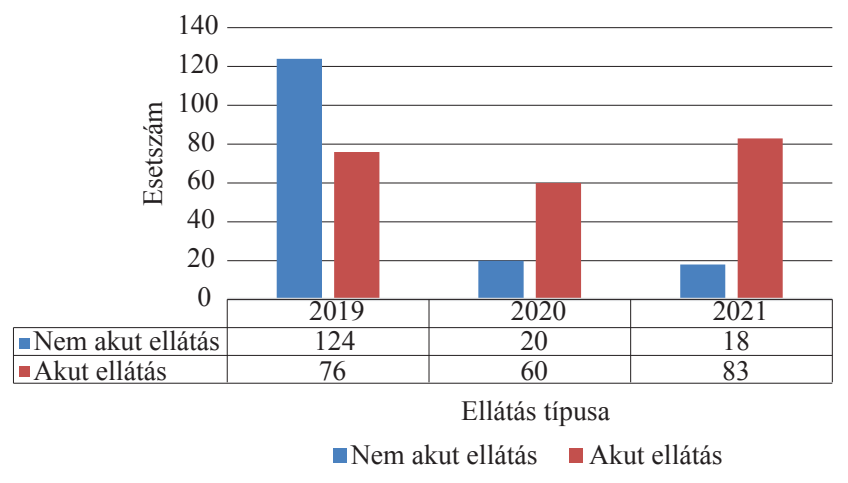

2. ábra $\quad$ A vizsgálati időszakokban elvégzett, tervezett és akut mútétek számadatai a beavatkozás típusa szerinti megoszlásban 
pedig ugyanez a korosztály jelen van, de megjelenése nem képvisel kiugróan nagy arányt. A 18-39 és a 40-49 éves korosztályú betegek aránya is eltért a három csoportban: az összes vizsgált beteg közül 2020-ban 20,78\%, míg 2019-ben 31\%, 2021-ben pedig 33,7\% volt. Az átlagéletkor vizsgálatánál a Levene-teszt alapján a szóráshomogenitás feltétele a három csoportban teljesült, $\mathrm{p}=0,736$ értékü volt. Egyszempontos variancia- elemzést végeztünk, amely $\mathrm{F}(2 ; 366)=1,274(\mathrm{p}=$ 0,281) volt, azaz a 2019-es, 2020-as és 2021-es évben az átlagéletkor varianciái nem mutattak szignifikáns különbséget.

A COVID-19-pandémia előtti és alatti vizsgálati populációk mútétet indikáló kódjai közül a tervezett és a sürgős ellátást igénylő esetek aránya nagymértékben különbözött. A 2. ábrán látható oszlopos diagram segítsé-

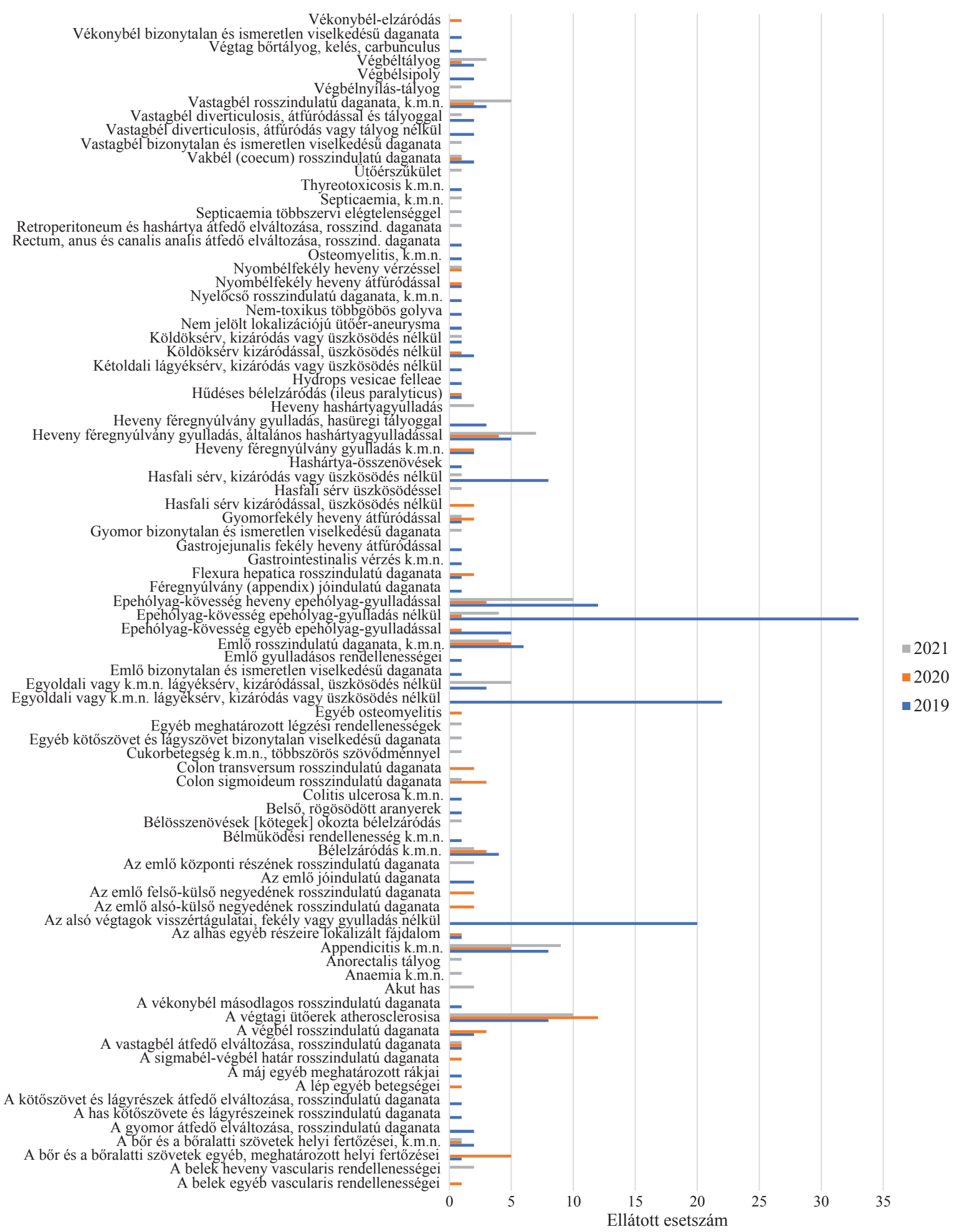

3. ábra $\mid$ Az ápolást indokló fódiagnózisok eloszlása az összes hasi sebészeti mútéten átesett beteg esetén 2019, 2020 és 2021 áprilisában 
gével szemléltetjük, hogy 2019-ben 124 tervezett és 76 akut sebészeti beavatkozás volt, míg 2020-ban 20 tervezett és 60 akut, 2021 azonos időszakában pedig 18 tervezett és 83 sürgős sebészeti beavatkozás történt. Napi átlagban az adott hónap összes napját figyelembe véve 2019-ben 2,54, míg 2020-ban 2, 2021-ben 2,8 akut mútét történt. A munkanapokat számításainkban figyelembe véve 2019-ben napi átlagban 6,2, míg 2020-ban napi 1, 2021-ben napi 0,9 tervezett általános hasi sebészeti mütét történt. A COVID-19-járvány miatti szabályok értelmében 2020 és 2021 áprilisában a tervezett mütétek túlnyomó többségben daganatos betegségek miatt kerültek kivitelezésre.

Az elvégzett mútétek ápolást indokló fődiagnóziskódjai (3-as típusú BNO) alapján a vírusfertőzés lassítását célzó korlátozások hatására egyértelmúen változott a fekvőbeteg-ápolást indokló fődiagnóziskódok összetétele (3. ábra). A 2019-es évhez képest 2020-ban nem végeztünk tervezett mútéteket (nem gyulladt, köves) epehólyag, egyoldali kizáródás nélküli lágyéksérv és visszértágulat miatt. 2021 áprilisában szintén minimális volt a felsorolt mútétek száma, azzal a különbséggel, hogy az osztályon vagy a sürgősségi ellátásban többször epés görcs miatt jelentkezőknél az epehólyag- és a kizáródásra hajlamos sérv miatt többször megjelent betegeknél a lágyéksérvmútéteket elvégeztük (ez összességében elenyésző mennyiségü, 2 esetben jelentett tervezett mütétet). A daganatos betegségek (az emlő, a vastag- és végbél rosszindulatú vagy bizonytalan eredetű daganata) miatti tervezett mütétek arányának emelkedése az összes többi tervezett mütét számának csökkenése miatt volt észlelhető 2020 és 2021 áprilisában, számuk 2019-hez képest (22 eset) 2020-ban 14\%-os (19 eset), 2021-ben 27\%-os (16 eset) csökkenést mutatott. Szembetűnően változott 2019-hez képest 2020-ban az akut ellátásra jellemző diagnóziskódok összetétele. A vakbélgyulladással diagnosztizáltak száma közel 30\%-kal, az epehólyaggyulladással diagnosztizált betegek száma több mint 60\%-kal csökkent 2020 áprilisában 2019 azonos hónapjához képest. A 2020-as betegforgalomra jellemző volt továbbá, hogy a fekvőbeteg-ellátást igénylő tályog- és érszúkülettel kapcsolható ápolást indokló diagnózisok száma kissé emelkedett a korábbi év azonos időszakához képest. A 2021 -es évben az epehólyag- és a vakbélgyulladás miatti műtéti számok a 2019-es évivel közel azonosak voltak, de emelkedést mutattak a kizárt sérv és periproctalis tályog diagnózisok esetszámai is (4. ábra).

Összehasonlítottuk a három időszakban mútétre került betegek orvosi dokumentációjában fellelhető kísérő diagnózisok mennyiségét. Az 1 főre jutó kísérő diagnózisok (5-ös BNO-k) száma 2019-ben 1,69 volt, míg 2020-ban 2,97, 2021-ben pedig 2,74. Ha csak azokat a betegeket vizsgáltuk, akiknél volt valamilyen kísérő betegség kódolva, akkor 2019-ben 2,5, 2020-ban 3,75, 2021 -ben pedig 3,25 volt ezekben a csoportokban az 1 főre jutó kísérő diagnózisok száma. A különböző években megjelent betegek kísérődiagnózis-mennyiségének átlagát egyszempontos varianciateszttel is vizsgáltuk. A Levene-teszt szerint a szóráshomogenitás feltétele nem teljesült $(\mathrm{p}=0,036)$. ANOVA-próbát végeztünk, amelynek eredménye $(\mathrm{F}(2 ; 271)=10,002 ; \mathrm{p}<0,0001)$ szignifikáns volt, tehát a különböző időszakok kísérő diagnózisainak átlaga között volt eltérés. A post hoc vizsgálatok közül a Tamhane-módszert alkalmazva azt találtuk, hogy a 2019-es év kísérődiagnózis-átlaga szignifikánsan eltér a 2020-as és a 2021-es csoport átlagaitól $(\mathrm{p}<0,001$ és $\mathrm{p}=0,026)$. Ezzel szemben a 2020 -as és a 2021-es csoport kísérődiagnózis-mennyiségének átlagai egymástól nem tértek el szignifikánsan ( $\mathrm{p}=0,386)$.

Összehasonlítottuk a sürgősséggel operált betegek adatait is. 2019-ben 76, 2020-ban 60, míg 2021-ben 83 mútéti eset történt sürgősséggel egy hónap alatt. A betegek korcsoportos eloszlásában a 40-49 éves korosztály adatai között volt kiemelhető eltérés: 2021-ben közel négyszer (15 fó), 2019-ben pedig pont négyszer annyi (16 fó) volt a betegek létszáma a korcsoportban, mint 2020-ban (4 fö). A sürgösséggel operált betegek kísérő diagnózisainak szóráshomogenitása Levene-teszttel nem tért el egymástól szignifikánsan $(\mathrm{p}=0,827)$. ANOVAteszttel vizsgáltuk a kísérő betegségek szórásátlagát,
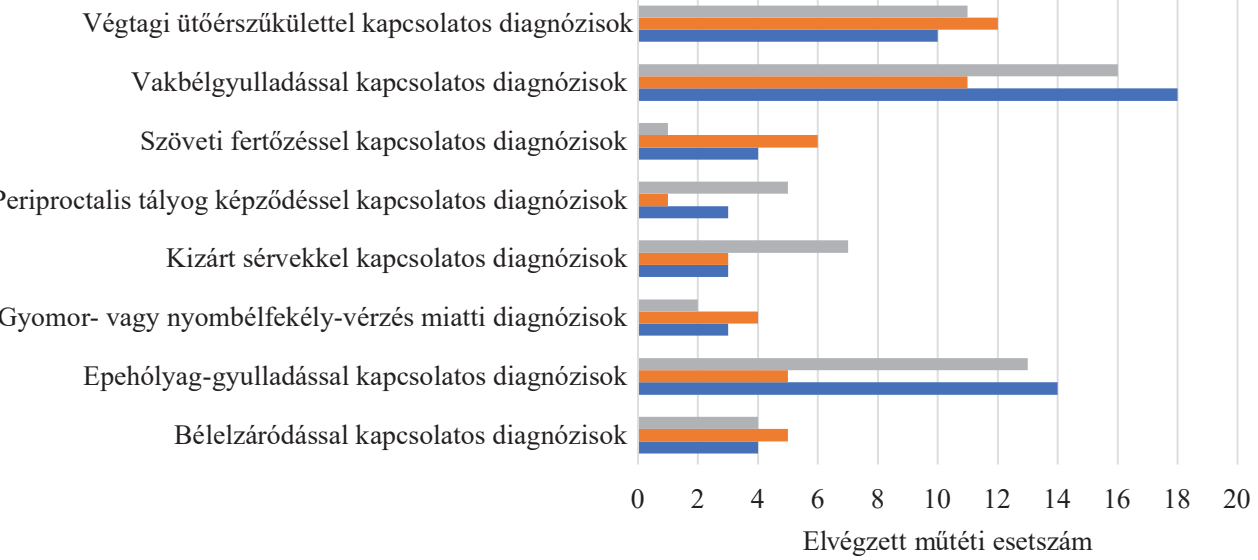

$2021 \square 2020 \quad \square 2019$

4. ábra |Az akut hasi sebészeti beavatkozásoknál kódolt leggyakoribb, ápolást indokló fődiagnózis-csoportok eloszlása a három vizsgálati időszakban 
amelynek eredménye szerint nem volt szignifikáns különbség a három csoport átlagai között $(\mathrm{F}(2 ; 92,06)=$ $2,509 ; \mathrm{p}=0,087)$. Az akut mütéten átesett betegek szövődménydiagnózisait is összegyưjtöttük mindhárom csoportban: 2019-ben 2,08, 2020-ban 2,11 és 2021ben 3,25 szövődménykód jutott átlagosan az akut betegekre. A szövődménykódok mennyiségének átlagait vizsgálva a Levene-teszt alapján a szóráshomogenitás kritériuma fennállt, az ANOVA-teszt azonban nem adott szignifikáns eredmény $(\mathrm{F}(2 ; 34)=0,79 ; \mathrm{p}=0,462)$, azaz nem volt szignifikáns különbség a három időszakban vizsgált akut betegek szövődménykód-mennyiségének átlagában.

A vizsgálati populáció halálozási adatait összehasonlítva 2020-ban 9, 2021-ben 13, míg 2019-ben 10 beteg hunyt el hasi sebészeti mútétet követően azonos intézeti bennfekvési időszak alatt. Az elhunyt betegek közül 2019-ben 9, 2020-ban 8, 2021-ben pedig mind akut felvétel miatt került intézetünkbe, és sürgősségi mútéten esett át. Az akut sebészeti ellátásban részesült betegek halálozása 2019-ben 11,8\%, 2020-ban 13,33\%, 2021ben 15,66\% volt. Az elhunytak közül 2021-ben 7 beteg volt érintett a COVID-19-fertőzéssel, 3 beteg esett át igazoltan a felvételét megelőzően COVID-19-fertőzésen, 3 betegnek PCR-teszttel igazoltan COVID-19-fertôzése zajlott az adott intézeti megjelenése során, és az érintett betegek közül 1 kontaktszemély volt.

A COVID-19-pandémia első hullámából a kiemelt időszakban (2020. április) PCR-teszttel igazolt COVID-19-fertőzött hasi sebészeti beteg nem került mütétre a hasi sebészeti vagy az intézet más osztályáról. Ezen időszak alatt 1 érsebészeti betegről derült ki a posztoperatív időszakban, hogy koronavírus-fertőzése zajlott, minimális tünetekkel átvészelte a betegséget. 2021 áprilisában 21 beteg volt érintett COVID-19-fertőzéssel a vizsgált betegek közül. 11 beteg a felvétele időpontjára már átesett a fertőzésen, 5 betegnek az osztályos felvételkor elvégzett PCR-tesztje lett pozitív, ók COVID-osztályon kerültek elhelyezésre további ellátás céljából. 5 további beteg pedig a sebészeti osztályon történt kórtermi kontaktálódás miatt kontaktszemélyként a kórház COVID intermedier osztályára került áthelyezésre további fekvőbeteg-ellátás céljából.

\section{Megbeszélés}

2020-ban az egészségügyi korlátozások és vélhetően a COVID-19-fertőzéstől való félelem $[10,11]$ átrendezte a hasi sebészeti ellátás palettáját. A nemzetközi trendeket követve [10, 12-17] a COVID-19-pandémia elleni küzdelem korlátozó rendelkezései [1] miatt radikálisan csökkent a tervezett hasi sebészeti beavatkozások aránya. A COVIDSurg Collaborative tanulmány szerint a COVID-19-járvány első hullámának 12 hetes periódusa alatt világszerte a tervezett és a jóindulatú daganatos betegségek miatti mútétek $81,7 \%$-a, a rosszindulatú daganatos betegségek miatti mútétek 37,7\%-a elmaradt [13].
Egy, az Amerikai Egyesült Államokban végzett kutatás alapján a délkeleti államokban a tervezett sebészeti ellátások 97\%-át törölték 2020 tavaszán [14]. Vizsgálatunkban 2020 és 2021 áprilisában a tervezett, nem rosszindulatú tumoros betegség miatti altatásos mütétek a szakirodalmi példákhoz hasonlóan közel 100\%-ban maradtak el. A rosszindulatú elváltozások daganatterápiájához kapcsolódó tervezett beavatkozások, több publikált szakirodalmi példával [13-15] szemben, az adott három vizsgálati időszak alatt elvégzésre kerültek. A tervezett, daganat miatti műtétek száma kismértékben ugyan csökkent, de az elmondható, hogy a COVID-19-fertőzéstől szenvedő betegek ellátása nem akadályozta számottevően a rosszindulatú daganatos betegek mútéti ellátását a sebészeti osztályon. 2020-ban a hasi sebészeti mútéti ellátást igénylő sürgősségi forgalom körülbelül 20\%-kal alacsonyabb volt a korábbi év azonos időszakához képest. 2021-ben a 2020-ban látott forgalomcsökkenés nem volt tapasztalható: 83 akut eset került ellátásra, ami körülbelül 10\%-os forgalomnövekedést jelzett a 2019ben tapasztalt sürgősségi ellátáshoz képest (76 eset). A 2020-as sürgősségi forgalomváltozást magyarázza, hogy a sürgősségi sebészeti megjelenések előfordulása a nemzetközi szakirodalom alapján világszerte csökkent az első hullámban, ami összefüggött a „lezárás (lockdown)” jelenségével [10, 12, 16-18]. A nem COVID-19-fertőzéssel összefüggő sürgősségi ellátás visszaesése részben a kórházban elkapható koronavírustól való félelem [10], részben az egészségügyi ellátásokkal kapcsolatos központi kommunikáció $[8,10,19]$ hatására alakult ki. Az akut hasi mútéteken átesett betegeknél több nemzetközi kutatás eredménye szerint [16, 18] 2020-ban magasabb volt 2019-es évhez képest a posztoperatív halálozás aránya. Vizsgálatunk eredményei alapján a nem COVID19-ellátással összekapcsolható sürgős hasi mútéteket követő intézeti elhalálozás nem mutatott szignifikáns eltérést a három időszakban, ami összhangban van nemzetközi megfigyelésekkel [19, 20].

A betegek kísérő betegségeinek statisztikai elemzésekor egyértelmú eltérés volt 2019 és 2020, 2021 adataiban: az utóbbi két évben több, kísérő betegséggel rendelkező beteg került mütétre osztályunkon. Hasonló eredményekról számolt be Cano-Valderrama multicentrikus spanyol kutatásában [20]. McLean és mtsai [16] a pandémia miatti lezárás utáni időszakban esendőbb általános állapotú, idősebb és több kísérő betegséggel adminisztrált betegek felvételéról számolt be a lezárás előtti időszakhoz képest. A kísérő betegségek számának eltérése a jelen kutatásban az elhunyt betegeknél nem volt számottevő, ezért arra a következtetésre jutottunk, hogy elsősorban a mütétet indokló betegség előrehaladott állapota (például szepszis) befolyásolta a mortalitási mutató alakulását, ami az adminisztratív adatokban nem egyértelműsíthető megfelelően, ezért a későbbiekben módszertani fejlesztés szükséges a pontosítás céljából. Kutatásunkban, kiemelve az akut betegek kísérő betegségeinek, szövődményeinek vizsgálatát a különböző ellátási 
időszakokban, nem találtunk szignifikáns eltérést a szórások között, ami további kutatások, módszertani fejlesztés szükségességét veti fel a pontosabb vizsgálat céljából. A sürgősséggel felvett betegek ápolást indokló födiagnózisainak (mûtétet indokló betegségeinek) összetételében eltérést találtunk a vizsgálati időszakokban. 2020-ban magasabb arányban fordult elő végtagi ütőérszúkület, szöveti gyulladás, és csökkent a gyulladt epehólyag diagnózisainak használata (3. ábra) a korábbi év azonos időszakához képest. A jelenség összefügg azzal, hogy az epehólyag-gyulladás okozta panaszokra - a Magyar Sebész Társaság honlapján is megfogalmazott javaslatokkal [7] vagy a nemzetközi szakirodalomban $[5,15,19]$ is publikált telemedicinai, háziorvosi konzultációkkal összhangban - vélhetően konzervatív kezelést alkalmaztak, ami csökkentette az epehólyag-gyulladással kapcsolatos fekvőbeteg-ellátás terhelését 2020 áprilisában. A bőrtályog diagnózisával, a periproctalis tályoggal összefüggő diagnózisok arányának emelkedése a mütétre került fekvő betegek körében szintén felveti, hogy a betegek hosszabb ideig próbálták nem kórházi keretek között, esetleg otthon kezelni önmagukat. Korábban a hasonló betegségek feltárása inkább a járóbeteg-szakellátás keretében történt, 2020 és 2021 tavaszán azonban a korábbi év azonos időszakához képest vélhetően az „előrehaladott” állapottal volt összefüggésben a megjelenések gyakoriságának emelkedése a fekvőbeteg-ellátásban. A COVID-19-járvány első és harmadik hulláma alatt az operált betegek életkori összetétele szintén változott 2019 azonos időszakához képest. 2020-ban megfigyelhető volt, hogy az 50 éves korosztályban operált betegek száma csökkent, ami az elmaradt tervezett mútétekkel (például köves, de nem gyulladt epehólyag eltávolítása, alsó végtagi visszérmútét, lágyéksérvmütét) függött össze.

Sok nemzetközi kutatás beszámolt arról, hogy a COVID-19-pandémia ideje alatt csökkent a sürgősségi sebészeti ellátások száma. Több publikáció [12, 18-21] figyelemfelkeltőnek véleményezi, hogy a kezdődő és nem súlyos vakbélgyulladás és epehólyag-gyulladás konzervatív - sok esetben háziorvos vagy telemedicina által koordinált - kezelésének előtérbe kerülése és sikeres ellátása a korábbi gyakorlattal szemben csökkentheti a sürgősségi fekvőbeteg-ellátás terhelését a pandémia lezajlása után is. A jelen, kis esetszámú vizsgálat során 2020 áprilisában valóban csökkent az akut hasi sebészeti ellátások aránya, a következő évben azonban hasonló COVID_19-szabályozás mellett ez az eltérés nem volt tapasztalható, és a pandémia előtti időszakra jellemző mennyiségben kerültek epehólyag- és vakbélgyulladással mütétre betegek. A forgalmi adatok alapján a 2020 áprilisában tapasztalt változások a sürgősségi ellátásban átmeneti jellegünek tekinthetők, melyeket befolyásolhatott a járványkezelési stratégia, a „lockdown” jelenség, a betegellátás szervezésének gyors átalakítása és a betegek félelme a koronavírus-fertőzéstől.

A szerzőkben felmerült, hogy az epehólyag-kövesség és -gyulladás miatti, tervezett és akut mútéti szám 2020. áprilisi csökkenése magával vonhatja-e a - járványon kívüli - normál egészségügyi ellátás esetén a fenti betegségek kezelési stratégiájának, a mütét indikációinak felülvizsgálatát. A kérdés megítélésére további célirányos vizsgálatok lennének szükségesek.

Kiemelendő, hogy igazolt COVID-19-fertőzött betegek hasi sebészeti mútéti ellátása 2020 és 2021 áprilisában az adott sebészeti osztályon nem okozott ellátásbeli nehezítettséget a csekély esetszám miatt. Az alacsony számú COVID-19-fertőzöttség, a betegek szeparálása a járványügyi ajánlások alapján jelentett némi szervezési nehézséget, de összességében a nem COVID-19-fertőzött betegek sürgősségi, tervezett, tumor miatti ellátása zavartalanul megtörtént a vizsgálati időszak alatt 2020ban és 2021-ben is.

\section{Korlátok}

A jelen kutatás során számos korlátot azonosítottunk. A legnagyobb korlát az volt, hogy a felvételre került betegek általános állapotát, a különböző társbetegségeknek és az ápolást indokló betegségeknek a súlyosságát adminisztratív nehézségek miatt nem lehetett pontosan rögzíteni a kódok által annak ellenére, hogy a vizsgálatban részt vevőknél korrigáltuk az informatikai rendszer hiányosságait. A bevonási kritériumokat figyelembe véve kevés aktív COVID-19-fertőzésben szenvedő, akut hasi sebészeti beavatkozáson átesett beteg adata került vizsgálatra, ami miatt a COVID-19-fertőzés hatásainak vizsgálata nem volt kivitelezhető. A kijelölt három hónap vizsgálata továbbá rávilágított arra, hogy nagyobb időintervallumok adataival, nagyobb esetszámú elemzésekkel megbízhatóbb képet kaphatunk a betegforgalmi adatok változásáról.

\section{Következtetés}

A COVID-19-járvány miatt bevezetett járványügyi intézkedések velejárója volt, hogy hasi sebészeti osztályunkon lényegesen kevesebb tervezett mütétet végeztünk. A sürgősségi esetek kísérő betegségeinek száma szignifikánsan emelkedett, a COVID-19-fertőzésben elhunytakon kívül valószínúleg ezzel magyarázható a halálesetek számának párhuzamos emelkedése.

Kutatásunkkal szeretnénk felhívni a figyelmet a koronavírus-járvány miatt az egészségügyi ellátás kényszerü megváltozásából adódó klinikai munkánk során tapasztalt (nem a vírusfertőzés okozta) következményekre. A későbbiekben javasolt nagyobb esetszámú, részletesebb vizsgálat végzése, amely a koronavírus-járvány öszszes hullámában végzett sebészeti ellátás adatait is feldolgozza, és a járványkezelés miatti egészségügyi ellátás változásainak hatásaira fókuszál. A koronavírus-világjárvány további hullámainak időtartamát és hatását nehéz megjósolni, félő azonban, hogy a COVID-19-et okozó vírus elleni védekezés miatt elhalasztott tervezett beavatkozások, szúrések és kontrollvizsgálatok elmaradása az 
elkövetkező években kedvezőtlen irányban fogják befolyásolni a sebészi ellátásra szoruló betegek perioperatív mortalitását és morbiditását.

Anyagi támogatás: A közlemény megírása, illetve a kapcsolódó kutatómunka anyagi támogatásban nem részesült.

Szerzői munkamegosztás: B. Zs.: Adatgyúités, irodalomkutatás, statisztikai számítás, a kézirat megírása, szerkesztése. M.-G. Zs.: A kézirat fogalmazása, véleményezése, szerkesztése. A cikk végleges változatát mindkét szerző elolvasta és jóváhagyta.

Érdekeltségek: A szerzóknek nincsenek érdekeltségeik.

\section{Köszönetnyilvánítás}

Szeretnénk ezúton is köszönetet nyilvánítani Varga Árpád informatikusnak a Bajcsy-Zsilinszky Kórház Informatikai Osztályáról, aki az adatbázis összegyújtésében segítségünkre volt, Nagy Évának, aki a Mikrobiológiai Részleg adatbázisából a COVID-19-fertőzésre vonatkozó adatokat biztosította. Végül, de nem utolsósorban köszönetünket fejezzük ki $d r$. Juhász Miklós osztályvezető úrnak, aki engedélyezte a sebészeti osztályon történő kutatás kivitelezését.

\section{Irodalom}

[1] National Institute of Public Health. Government instructions due to the COVID-19 pandemic in 2020 in Hungary. [Nemzeti Népegészségügyi Központ. Eljárásrend a 2020. évben azonosított koronavírussal kapcsolatban 2020. március 31.] Available from: https://koronavirus.gov.hu/sites/default/files/sites/ default/files/imce/nnk_eljarasrend_2020.04.01.pdf [accessed: March 9, 2021]. [Hungarian]

[2] World Health Organization, Regional Office for Europe. Coronavirus disease (COVID-19) pandemic. WHO, Copenhagen. Available from: https://www.euro.who.int/en/health-topics/ health-emergencies / coronavirus-covid-19/novel-coronavirus2019-ncov [accessed: March 8, 2021].

[3] World Health Organization. WHO Director-General's opening remarks at the media briefing on COVID-19. WHO, Geneva, 11 March 2020. Available from: https://www.who.int/directorgeneral/speeches/detail/who-director-general-s-opening-remarks-at-the-media-briefing-on-covid-19---11-march-2020 [accessed: March 8, 2021]

[4] National Health Service. 2nd-update-intercollegiate-generalsurgery-guidance-on-covid-19-5-april.pdf [accessed: May 9, 2020 .] NHS, London, 29 April 2020. Available from: https:// www.england.nhs.uk/coronavirus/wp-content/uploads/ sites $/ 52 / 2020 / 04 /$ second-phase-of-nhs-response-to-covid19-letter-to-chief-execs-29-april-2020.pdf [accessed: 23. 05. 2021].

[5] American College of Surgeons. COVID-19: guidance for triage of non-emergent surgical procedures. ACS, Chicago, IL, March 17, 2020. Available from: https://www.facs.org/covid-19/ clinical-guidance/triage [accessed: March 21, 2020]

[6] American Collage of Surgeons. COVID-19: elective case triage guidelines for surgical care. ACS, Chicago, IL, March 24, 2020.
Available from: https://www.facs.org/covid-19/clinical-guidance/elective-case [accessed: March 22, 2021].

[7] Hungarian Society of Surgery. Guidelines during the COVID-19 pandemic. [Magyar Sebész Társaság. COVID-19 Információk, ajánlások.] Available from: http://www.mst.hu/info.aspx?sp=31 [accessed: March 9, 2021]. [Hungarian]

[8] Government Decree No. 40/2020 (III. 11.) concerning the COVID-19 pandemic. [A Kormány 40/2020. (III. 11.) Korm. rendelete veszélyhelyzet kihirdetéséről.] Magy Közl. 2020; 39: 1353-1354. [Hungarian]

[9] Emődy-Kiss B, Pataki Á, Deli G, et al. A summary of characteristics of the first wave of new type coronavirus epidemic and potential association with tuberculosis vaccination. [Az új koronavírus okozta járvány első hullámának jellemzői és esetleges kapcsolata a tuberkulózis elleni oltottsággal.] Orv Hetil. 2021; 162: 123-134. [Hungarian]

[10] Rosenbaum L. The untold toll - The pandemic's effects on patients without Covid-19. N Engl J Med. 2020; 382: 2368-2371.

[11] Mantica G, Riccardi N, Terrone R, et al. Non-COVID-19 visits to emergency departments during the pandemic: the impact of fear. Public Health 2020; 183: 40-41.

[12] Dick L, Green J, Brown J, et al. Changes in emergency general surgery during Covid-19 in Scotland: a prospective cohort study. World J Surg. 2020; 44: 3590-3594.

[13] Nunoo-Mensah JW, Rizk M, Caushaj PF. Elective surgery cancellations due to the COVID-19 pandemic: global predictive modelling to inform surgical recovery plans. Br J Surg. 2020; 107: 1440-1449.

[14] Richmond BK, Dean LS, Farrell TM. The impact of the COVID-19 pandemic on surgical practice in the Southeastern United States: results of a survey of the membership of the Southeastern Surgical Congress. Am Surg. 2020; 86: 916-925.

[15] Giuffrida M, Cozzani F, Rossini M, et al. Covid-19 and elective general surgery. Acta Biomed. 2020; 91: e2020152.

[16] McLean RC, Young J, Musbahi A, et al. A single-centre observational cohort study to evaluate volume and severity of emergency general surgery admissions during the COVID-19 pandemic: Is there a "lockdown" effect? Int J Surg. 2020; 83: 259-266.

[17] National Health Service. A\&E attendances \& emergency admissions 2020-21. NHS, London. Available from: https://www. england.nhs.uk/statistics/statistical-work-areas/ae-waitingtimes-and-activity/ae-attendances-and-emergency-admissions-2020-21/ [accessed: May 20, 2021].

[18] Sá AF, Lourenço SF, Teixeira RD, et al. Urgent/emergency surgery during COVID-19 state of emergency in Portugal: a retrospective and observational study. Braz J Anesthesiol. 2021; 71: $123-128$.

[19] McGuinness MJ, Hsee L. Impact of the COVID-19 national lockdown on emergency general surgery: Auckland City Hospital's experience. ANZ J Surg. 2020; 90: 2254-2258.

[20] Cano-Valderrama O, Morales X, Ferrigni CJ, et al. Acute care surgery during the COVID-19 pandemic in Spain: changes in volume, causes and complications. A multicentre retrospective cohort study. Int J Surg. 2020; 80: 157-161.

[21] Neufeld MY, Bauerle W, Eriksson E, et al. Where did the patients go? Changes in acute appendicitis presentation and severity of illness during the coronavirus disease 2019 pandemic: a retrospective cohort study. Surgery 2021; 169: 808-815.

(Benedek Zsófia dr.,

Budapest, Felső Svábhegyi út 11., A ép. fszt. 4., 1125 e-mail: benedek.zsofi0411@gmail.com)

A cikk a Creative Commons Attribution 4.0 International License (https://creativecommons.org/licenses/by/4.0/) feltételei szerint publikált Open Access közlemény, melynek szellemében a cikk bármilyen médiumban szabadon felhasználható, megosztható és újraközölhetö, feltéve, hogy az eredeti szerző és a közlés helye, illetve a CC License linkje és az esetlegesen végrehajtott módositások feltüntetésre kerülnek. (SID_1) 